\title{
Mental Retardation and Society: The Ethics and Politics of Normalization*
}

\section{Susan Rose-Ackerman}

\section{INTRODUCTION}

During the sixties, social critics visited institutions for the retarded and were shocked by the conditions they found (Blatt and Kaplan 1966; Rivera 1972). Scholarly research supported the conclusions of lay observers (see the studies cited in Balla, Butterfield, and Zigler [1974] and Biklen [1979]). Consensus was easy: people saw conditions that everyone believed were bad, and all agreed that policies should change. Only a small percentage of the retarded were in institutions or helped by specialized public programs, and many had been excluded from school. Care was inadequate both because it was of low quality and because many of the retarded received no services. Social critics were allied not only with scholarly experts but with many who had a deep personal interest in programs for the retarded. Both parents and professionals who cared for the retarded sought changes in treatment and educational methods and increases in public funding. ${ }^{1}$ The key slogans were deinstitutionalization, normalization, mainstreaming, and a developmental model of care. ${ }^{2}$

* Partially funded by the Yale Program on Non-Profit Organizations. I wish to thank Anita Miller for originally interesting me in this topic, Bruce Ackerman for helping me think through the philosophical alternatives, and Marc Chupka for very able research assistance. I benefited from presenting the paper at the Regulation Seminar of the Yale Center for Health Studies in the Institution for Social and Policy Studies.

1. See, e.g., National Association for Retarded Children Five-Year Plan, Document B, "Service Goals and Achievement Strategies" reprinted in U.S. President's Committee on Mental Retardation (1977), pp. 59-61, hereafter cited as PCMR.

2. Several writers have tried to define these terms. The National Association of Superintendents of Public Residential Facilities for the Mentally Retarded claims that: "Deinstitutionalization encompasses three interrelated processes: (1) prevention of admission by finding and developing alternative community methods of care and training; (2) return to the community of all residents who have been prepared through programs of habilitation and training to function adequately in appropriate local settings; and (3) establishment and maintenance of a responsive residential environment which protects human and civil rights and which contributes to the expeditious return of the individual to normal community living, whenever possible" (quoted in Scheerenberger 1977, p. 3). An influential statement of the normalization principle was made by Nirje (1976) in an article first published in 1969. He states that the normalization principle "means making available to all mentally retarded people patterns of life and conditions of everyday living which are as close as possible to the regular circumstances and ways of life of society" (p. 231). See also Jones et al. (1975, p. 4) and Wolfensberger (1976). Mainstreaming, according to Wiegerink and Posante-Lobo (1977, p. 71), "means integration of exceptional children into the common flow of the educational system. It seeks an end to segregated special classrooms for the special children and a

Ethics 93 (October 1982): 81-101

(C) 1982 by The University of Chicago. All rights reserved. 0014-1704/83/9301-0007\$01.00 
This consensus is now falling apart. As shock and outrage are translated into particular programmatic changes, public policy toward the retarded has once again become a difficult and controversial issue. The retarded, their parents, and their professional advocates are only a small minority of the population. The severely and profoundly retarded are an even smaller group. ${ }^{3}$ To change policy, the minority must generate support from the general public. Sympathy, however, is easier to obtain than tax dollars and private monetary donations. This places activists for the mentally retarded in a difficult position. A clear, simple message is easier to use as a rallying cry than a balanced and complicated assessment of the relative merits of alternative policies. The principles of normalization and deinstitutionalization would, however, be expensive if consistently translated into policy. Even the most impassioned advocates may be forced to lay aside principle in the competition for funds. Under the pressure of scarce resources, cracks appear in the alliance of legal activists, mental retardation professionals, and parents (cf. Roos 1979). The tensions not only represent clashes between private interests and moral principles but also reveal fundamental philosophical disagreements. The debate, however, has seldom moved behind the slogans to examine the underlying premises of the normalization movement.

The examination of premises is not an easy task since the advocates themselves are not particularly concerned with consistency. Therefore, Section II of this paper begins with philosophy and asks how several general normative political theories would deal with the mentally retarded. I show that some common normative positions that are perfectly serviceable in most contexts are incoherent when applied to mental retardation, but that other classes of theories do generate internally consistent views. Section III, then, discusses the relationship between these theories and the positions of advocates and illustrates the way principles conflict with each other under plausible interpretations of the facts. Section IV explores the links between private interests and philosophical principles and explains why

beginning of provision for their special needs in the regular classroom." The developmental model is presented as a contrast to a "medical" model that views retardation as an incurable medical problem (Wolfensberger 1976, pp. 38-39). Wolfensberger (1976, p. 44) characterizes the developmental model as one that takes "an optimistic view of the modifiability of behavior, and usually it does not invest the differentness of the retarded person with strong negative value. Even if severely retarded, he is perceived as capable of growth, development, and learning."

3. The American Association on Mental Deficiency (AAMD) defines mental retardation as "substantially subaverage general intellectual functioning existing concurrently with deficits in adaptive behavior, and manifested during the developmental period" (quoted in Brewer and Kakalik 1979, p. 88). "Subaverage" means an IQ of at least two standard deviations below the mean (about 70 or below). Thus, if intelligence is, in fact, normally distributed, this implies that 2.3 percent of the population is retarded (or 4.67 million people in 1970). The National Association for Retarded Citizens (NARC), however, uses a rate of 3 percent $(6.1$ million people in 1970). The severely and profoundly retarded population is estimated by NARC to be about 5 percent of the total number of retarded persons or 0.15 percent of the population. Severe retardation is defined by the AAMD as an IQ between 20 and 35. The profoundly retarded have IQs of less than 20 (Brewer and Kakalik 1979, pp. 89-90). Many researchers recognize, however, that IQ tests are an inadequate guide in many cases. They turn instead to a developmental definition-e.g., children "with a major deficit in more than one of the basic developmental areas of language, self-help skills, motor skills, or socialization and who require extensive structure for learning to occur" (Fredericks et al. 1978, p. 192). 
some past alliances are breaking up. Section $\mathrm{V}$ considers the way the advocates of normalization have been forced to compromise their principles to obtain funds and points to the range of hard choices confronting both politicians and advocates for the retarded. Thus, Sections II and III show that basic principles matter in the sense that they have different policy implications. Sections IV and V go on to show that ideas are not the only things that matter in a realistic political setting (cf. Roos 1979; Conley 1973, chap. 7).

\section{NORMATIVE PRINCIPLES}

\section{A. Choice-based Theories}

Two kinds of philosophical position cannot satisfactorily deal with mental retardation. I shall call these the choice-based and class-based approaches. The most familiar example of a choice-based theory seeks to maximize the dollar value of producers' and consumers' surplus. Net benefits are calculated by asking people to specify either how much they would pay to obtain a benefit or how much they must be paid to accept a loss (for a standard treatment, see Baumol [1977, pp. 496-500]). The main difficulty is the design, even in principle, of the required thought experiments. Suppose, for example, that we are considering the provision of services to the severely mentally retarded. For some level of transfer, all people may be made better off. The program is Pareto preferred to the status quo since those of normal intelligence sympathize with the retarded and are willing to be taxed to help them (Hochman and Rodgers 1969). At some point, however, this ceases to be true. How then do surplus maximizers proceed? How are they to measure the gainers' willingness to pay? The thought experiments may be beyond the capacity of the severely retarded. Even when provided with measuring rods commensurate with their experience, one might be unable to communicate the rather complex notion of compensation: for example, How many tokens or cigarettes would you give up in return for learning to dress yourself or eat with a fork ? $^{4}$ Ir contrast, most mildly retarded individuals can be taught to make independent choices (Edgerton 1967; Baker, Seltzer, and Seltzer 1974; Kennedy 1966). Therefore, for these people, education may be designed with this goal in mind. It does not seem possible, however, to use a choice-based methodology to measure the benefits of this kind of education. Asking people to choose the value of learning to choose is incoherent. Asking people who have learned to make choices how much this education is worth is almost as difficult to fathom. A person is not obviously the same choosing entity both ex ante and ex post. ${ }^{5}$

One method of carrying out the thought experiments needed to assess benefits is particularly unsatisfactory. Some analysts have suggested that we compare the gains and losses of various actors by "putting ourselves in the other person's

4. Abstract thinking is beyond the capabilities of many retarded people, especially those at the low end of the distribution of intelligence. Many people who are severely and profoundly retarded can be taught some basic skills. Teaching methods for both children and adults, however, generally involve breaking a task down into a series of small pieces, with constant repetition, and immediate reinforcement of good performance with praise, gold stars, or tangible rewards like cigarettes or candy. Thus, the retarded are rewarded for learning, not given the choice of smoking a pack of cigarettes a day or learning to take a shower on their own. (See Matson, Marchetti, and Adkins 1980; Sanders 1975; Yates 1970.)

5. The problem is similar to the difficulties that arise in attempts to value life (see Broome [1978] and comments by Buchanan and Faith [1979], Broome [1979], Jones-Lee [1979], and Williams [1979]). 
place" (see Suppes [1966] and Sen's critique [1970, pp. 146-50]). On the one hand, our imaginative powers are not well developed enough to permit us to assert with any confidence that we can understand the benefits to a severely retarded person of learning to dress himself. On the other hand, it seems to be a contradiction in terms to imagine that a retarded person can put himself in the place of those of normal intelligence to assess the value of programs designed to develop IQ.

Of course, the less seriously retarded a person is, the more operational are standard cost-benefit techniques that rely on hypothetical choices. A job training program may succeed in raising a person's earning capacity. These benefits can then be compared fairly easily with training costs. The benefits to the person of self-sufficiency and integration into the larger society are difficult to measure, but some of the gains are captured by measuring earnings (see Conley [1973, pp. 287-300], who reports very high benefit-cost ratios for vocational training and education).

\section{B. Class-based Theories}

The second type of theory groups people into broad classes and discusses distributive justice only with respect to these classes. In such theories, the definition of a class is of central importance. Thus, John Rawls (1971) argues that justice requires that society maximize the position of the "worst-off class." Rawls (1979, p. 11) disclaims any attempt to deal with the handicapped, and it is not hard to see why they create problems. If the worst-off class includes only the severely handicapped and the terminally ill, then the rest of Rawls's argument implies a massive redistribution to them. Alternatively, if the worst-off class includes the bulk of the poor and working-class population, then the handicapped become a trivial minority who may actually be worse off in the Rawlsian world than in a utilitarian one. (See Ackerman [1980, pp. 266-72] for a fuller critique of Rawls on these grounds.)

Karl Marx provides another familiar class-based theory. Marx concentrates on the exploitation of the working class and has relatively little to say about people of genuinely low productivity (Robinson 1966, p. 12, n. 2). In the transitional stage of socialism, people would earn different amounts depending upon their abilities. Under communism, however, a person's "needs and desires, rather than his contribution of labor, will be the basis for the distribution of goods" (Lakoff 1964, pp. 223-24). Thus, the unproductive would presumably benefit in the final stage of communism, but Marx provides no discussion of how much redistribution would be justified. Before this final stage is reached, Marxism has very much the same implications as Rawls's work for policy toward the retarded and handicapped: they are submerged in the proletariat and get no special treatment.

\section{Respect-based Theories}

A class of philosophical work stresses each individual's right to equal respect as a person. To understand this position, one must explain who is to be counted as a "person" and what is meant by "equal" and by "respect." Some people draw a sharp line between the biologically human and other animals. This sharp line has been "justified" theologically by claiming that biologically human beings are made in the image of God (Allen and Allen 1979, pp. 139-40). But for the more secularly inclined, it seems difficult to make a biological distinction in a principled way. Singer (1976) calls the attempt "speciesism" and properly analogizes it 
to racism. Instead of emphasizing biological characteristics, some philosophers stress the capacity for rational discussion (Ackerman 1980) or the ability to make autonomous choices as the characteristic that justifies respect. (Thus, Kant [1976] uses the term "self-consciousness" to distinguish humans from animals.) If one's standards are not too high, then a large proportion of those classified as moderately and mildly retarded could probably pass a minimal autonomy or rationality test. Most can master daily living skills with only somewhat more difficutly than other people, ${ }^{6}$ and many people classified as retarded by school authorities live "normal" adult lives (Edgerton 1967; Kennedy 1966). Yet, even under a minimal test, most of the severely and profoundly retarded and perhaps some in the moderate and mild categories would have no "right" to equal respect. (Cf. Montague [1980, p. 384]; Regan [1980, p. 321] conjectures that Kant would include severely retarded humans in the unselfconscious group.) Respect-based theories thus have little to say about how society should treat those who are not entitled to equal respect. One might simply apply different theories to each group. See, for example, Nozick's discussion (1974, pp. 39-47) of "Kantianism for people, Utilitarianism for animals." (Nozick, however, avoids any discussion of defective members of a species [p. 45n.].)

Having defined the relevant class, one must still explain how to give each person "equal respect." At least two quite different interpretations can be given. The first approach emphasizes formal legal equality. Everyone who is labeled a "person" is entitled to the same set of legal rights, and no one can claim special rights on the basis of his or her mental capacities. Just as the genius cannot insist on privileges, neither can the mentally retarded person demand special benefits. On this theory, retarded persons can marry, vote, have children, sign contracts, etc. They can live, work, and spend their leisure time wherever they choose, subject only to the constraints of talent and income. This formal equality, however, may lead some mildly retarded people to fail in especially obvious ways, so that they live in poverty and loneliness and do not view themselves as people with substantial control over their own lives. They have the same "right to fail" as anyone else, but they may exercise this right with greater frequency than other people.

In contrast, the second approach to equal respect is concerned with "effective autonomy." It seeks to avoid situations where people feel that they have no personal control over their lives. Using this second criterion, policies should be designed to encourage retarded people to make rational choices in some areas of their lives even though many of them would be unable to live successfully on their own. Thus, the effective autonomy of moderately retarded people might be enhanced by a life which permits choices to be made in a controlled environment where serious failure, embarrassment, and shame are prevented. Policies to encourage sheltered work and recreation might be recommended, or even the placement of some retarded people in a setting like one of the Camphill sheltered villages where choice is encouraged in an isolated community protected from many of the pressures of the larger society (Baker, Seltzer, and Seltzer 1974).

6. Some mildly retarded people, however, do need training to improve their personal appearance and to control behavior that would interfere with employment (Sanders 1975, pp. 38-80). The management of money presents particular difficulties (Schalock and Harper 1978). Edgerton (1967) and Baker, Seltzer, and Seltzer (1974) stress the importance of both emotional stability and training for independent living. 


\section{Happiness-based Theories}

A final group of theories concentrates not on respect but on happiness. Although happiness is never easy to measure in a meaningful way, one need not depend on the methodology of choice-based theories. While a choice-based test requires a person to conceive of well-specified hypothetical alternatives, a happiness-based theory does not require the person himself to carry out such thought experiments. Even though it makes no sense to ask profoundly or severely retarded people how much they would choose to pay to receive a benefit, it nevertheless may be possible to decide whether they would be happier if they could dress themselves or drink from a cup. If one can meaningfully assess the happiness of a dog or an infant, there does not seem to be any special conceptual difficulty in assessing the happiness of the retarded.

I shall distinguish two different happiness-based theories: utilitarianism adds satisfaction levels together and tries to maximize the total, ${ }^{7}$ egalitarianism seeks to make all people equally happy. ${ }^{8}$

A consistent utilitarian position would take account of the happiness of all sentient beings (Bentham 1976; Mill 1976; Singer 1976). Thus, Bentham argues that animals should be included in the felicific calculus because of their capacity for suffering. To exclude either animals or severely and profoundly retarded people, the utilitarian would have to introduce some other principle besides "happiness" or else make the empirical claim that these beings cannot experience pleasure or pain.

To maximize the total utility of a given group of sentient beings, one seeks to find the point where the marginal utility of extra resources is equal for all entities. Thus, utilitarians are not interested in compensating a retarded person to make up for his or her handicap. Instead, they want to know how much extra happiness the retarded person obtains from an extra input of resources. Since the "production function" for happiness is not well understood, the literature contains a number of conflicting guesses. Thus, utilitarians and their critics sometimes disagree on the marginal utility of income to the handicapped. Lerner (1944, p. 40) states that his utilitarian argument in favor of equality "does not rule out particular cases where some reason may be given for particularly high or particularly low needs, for instance, of invalids on the one hand or ascetics on the other." Sen (1973, pp. 16-18), in contrast, claims that a utilitarian would favor normal people over cripples on the ground that cripples have a lower marginal utility of income at each income level. Conley (1973, p. 162) states: "Mental retardation will reduce a person's ability to enjoy leisure in the same way that it reduces a person's ability to earn in paid employment," but he does not offer any evidence. Nevertheless, it is

7. Utilitarianism has frequently been described as seeking "the greatest happiness for the greatest number." The meaning of this statement is unclear, however, since it does not specify whether per capita or total happiness is to be maximized. Clearly, if one is concerned with issues of birth control, abortion, and population policy, these two criteria yield very different results. The issue arises in the discussions of mental retardation when parents must decide whether to abort a defective child or withhold medical care from a severely handicapped newborn (Allen and Allen 1979, pp. 30-62). Since I do not deal with these issues here, I can take the population as fixed. In that case maximizing total happiness is identical with maximizing average happiness.

8. This is not, of course, the only meaning of egalitarianism, but it is the only one discussed here. See Lakoff (1964) and Rae (1979) for attempts to sort out the different meanings of this term. 
at least possible that marginal gains in the happiness of the retarded have high opportunity costs. Thus, a utilitarian might well conclude that large subsidies to the retarded are not justified.

Egalitarians, seeking to equalize satisfaction levels, are also not necessarily committed to large-scale transfers to the retarded. It is by no means obvious that there is a strong positive correlation between intelligence and happiness. If, in fact, a small quantity of material resources will make the retarded relatively happy with their lives, ${ }^{9}$ then an egalitarian will oppose expensive programs.

\section{FROM PHILOSOPHY TO ADVOCACY}

\section{A. A False Consensus}

Respect-based and happiness-based theories provide consistent positions from which to assess policy toward the mentally retarded. Each has its own hard cases and difficult line-drawing problems, but each can provide a framework for analysis. Most advocates for the retarded cannot, however, be associated clearly with any of these philosophical positions. Although many make arguments based on "moral" principles, they have seldom worked out the implications of their beliefs.

In particular, there is a basic tension between advocates for the retarded and others with a more general concern for social justice. Advocates tend to ignore the costs imposed on those who are not retarded. In contrast, people with more general concerns consider the entire population. Thus, a thoroughgoing "rights theory" must come to terms with the possibility that it may be impossible to "give everyone their rights" simultaneously, and a happiness-based theory must compare the utilities of all individuals. Any general theory that recognizes the scarcity of resources and takes account of the interests of all people is likely to conflict with the positions advanced by advocates for the retarded.

To avoid this confrontation, advocates often claim that community-based care and mainstream education are both cheaper and more effective than alternative policies (Center on Human Policy 1979). It is, however, by no means obvious that this is so. Although some research purports to have generated this result, it is of questionable quality. ${ }^{10}$ In particular, some cost studies have failed to recognize that, if more community-based facilities are made available, then more of the retarded may demand services. According to Conley (1973), only 5 percent of the

9. Gibbons and Gibbons (1980, pp. 602-4) review evidence on the self-concept of retarded children. One study (Fine and Caldwell 1967) found that educable mentally retarded (EMR) children often have very positive self-concepts which researchers dubbed "inaccurate, inflated and unrealistic." The U.S. Department of Labor (1979, p. A-121, table 23B) interviewed sheltered workshop clients in 1976 and found that the mentally retarded were generally satisfied. However, other research shows that many of the retarded are lonely, frustrated, and unhappy (Edgerton 1967; Baker, Seltzer, and Seltzer 1974). Evidence from the studies cited in Gibbons and Gibbons (1980) is mixed, and it is not clear whether those who are unhappy feel bad because they are retarded or because they have been poorly cared for.

10. These studies frequently overstate the net benefits of community-based care by failing to consider fixed costs appropriately and by neglecting to measure the costs of many of the services used by those in community-based facilities. The studies also do not measure how different types of retarded individuals would benefit from different types of programs, and they fail to consider the costs of monitoring a decentralized system. For critical reviews of the recent literature, see Heal, Siegelman, and Switzky (1978) and Wieck (1980, pp. 20-56). See Bradley (1978) for an attempt to alert policymakers to the hidden costs of deinstitutionalization. 
retarded are in residential institutions (over 50 percent of the severely and profoundly retarded). A program that is more attractive to the parents of mentally retarded youth and to mildly and moderately retarded adults than current programs can be very expensive for taxpayers if it is made available to all who demand service. If community-based care were one-fourth as costly as institutional care but led to the participation of 30 percent of the retarded, total budgetary costs would increase by 50 percent. These costs, however, must be balanced against the benefits to the retarded people and to their parents. It may be that the change in policy is justified on straight utilitarian grounds once the benefits to both the retarded people and their parents are calculated, but this is an empirical claim that would have to be demonstrated.

Advocates not only try to deny conflicts between their positions and more general political philosophies, but also seem to hold several potentially conflicting views simultaneously. The most common position is a hodgepodge of respectbased and happiness-based theories, along with some unsupported empirical claims. Thus, many legal activists who have argued court cases or lobbied for changes in laws emphasize formal legal equality at the same time that they call for large earmarked subsidies. The subsidies are to be used for programs that make the mentally retarded happy at the same time that they increase their capacity for autonomous choice. Much of the rhetoric implies that happiness-based and respect-based theories are compatible. Advocates argue that the problem of adjustment to independent living or to a regular school class is balanced by the individual's long-run gain in satisfaction with his or her life (e.g., Bronston 1976; Nirje 1976). This is, however, an empirical proposition that might or might not be true. Apparently, most of the retarded who live independently are fairly poor unless they have managed to marry a person of normal intelligence (Edgerton 1967; Kennedy 1966; PCMR 1977, p. 165). This is not surprising, but it does make clear that retarded people living in the community are unlikely to attain the average standard of living. If happiness is correlated with income, the retarded are unlikely to be very happy. ${ }^{11}$

Therefore, a potential for conflict exists, since some advocates see happiness as a means to the end of autonomy while others see autonomy as a means to the end of happiness. This tension is well illustrated by a 1978 court hearing concerning the implementation of a famous right-to-treatment case (Wyatt v. Stickney 344 F. Supp. 387 [M.D.Ala. 1972]). Professionals disagreed on whether deinstitutionalization was always to be preferred to high-quality institutional programs. Some stressed the need to push training for autonomous daily living as far as possible, while others pointed to the low marginal benefits relative to the costs and favored giving the mentally retarded pleasurable experiences (Rosenberg and Friedman 1979).

\section{B. Rights and "Normalization"}

Rather than confronting the inconsistencies in their positions directly, advocates have tended to assert a list of rights that ought to be guaranteed to the retarded. In many cases, however, it is difficult to identify the principle underlying the list, and

11. Cf. Roos 1979, pp. 616-17. For some empirical support for these concerns, see Baker, Seltzer, and Seltzer (1974), Budoff and Gottlieb (1976), Edgerton (1967), and O'Donnell and Bradfield (1976). Wolfensberger (1976, p. 52) quotes Governor Butler of Massachusetts who in the 1880s said: "A well-fed, well-cared for idiot is a happy creature. An idiot awakened to his condition is a miserable one." 
many rights would conflict with each other if systematically applied. The standard compilation includes the right to adequate income and employment, the right to live in the community, the right to habilitation, and the right to the "least restrictive" alternative (see, e.g., Schoenfeld 1974; the United Nations Declaration of the Rights of Mentally Retarded Persons, 1971 [reproduced in Allen and Allen 1979]; and "Rights of MR Persons: An Official Statement of the American Association on Mental Deficiency" [reproduced in Friedman 1976, pp. 179-86]). The list has been extended by some to include the right to be loved, the right to ignore gratuitous advice, and the right to happiness (e.g., Bronston 1976, p. 492; Wald 1976, pp. 5-17).

Some rights are especially difficult to defend because it is not clear that the rest of the population can assert these rights, however much they might like to do so. For example, in a speech in 1950 to the National Association for Retarded Citizens, one speaker asserted that retarded children have the "same right to happiness" as children everywhere (quoted in PCMR 1977, p. 40). Since most people, children as well as adults, are unhappy at least some of the time, it appears that few children are guaranteed this "right." In fact, although the right to the pursuit of happiness is frequently asserted, the right actually to attain happiness is seldom claimed by the general population. Furthermore, it is not obvious how society could make such a right operational, even if it were accepted.

These lists of rights are difficult to defend because advocates seldom take the first step of explaining why the mentally retarded are entitled to rights. While advocates assert that the retarded are entitled to respect, they consistently reject the idea that the mentally retarded must be capable of autonomous choice or rational discussion before they qualify (e.g., Feldman 1979; Gilhool 1976). Although it is seldom openly discussed, their position seems based on a latent speciesism which claims that all biological humans have certain rights. These rights do not appear to apply to dolphins and chimpanzees, but we are left to wonder why. (Cf. Regan [1980], who argues for animal rights by pointing to the rights granted to the mentally retarded.)

One group of advocates concentrates on formal legal equality. Using the analogy of racial and sexual prejudice (Gilhool 1976, p. 174), they are especially concerned with the pernicious effects of labeling. Those who emphasize formal equality have opposed special education for retarded children and special programs for retarded prisoners. These advocates frequently try to justify their position by pointing to the ineffectiveness of special programs (e.g., see Schwartz's [1976] response to Rowan [1976]). There is little attempt to deal directly with the tension between formal equality and effective autonomy.

The attempt to treat every biological human being with formal equality is especially difficult to sustain for those who are severely and profoundly retarded or who have multiple handicaps. These people will almost always be labeled since most of them cannot function normally in mainstream society. They pose a dilemma for those who support formal equality. A strict application of their principle would deny specialized services to severely and profoundly retarded people. Therefore, few advocates actually consistently espouse formal equality as the exclusive operative principle (Wald [1976] comes closest), asserting the argument only to gain benefits like the rights to vote, have children, and sign contracts.

A more common standard is the "normalization" principle which states that the retarded have the right to a range of goods and services that make their lives as "normal" as possible (Nirje 1976). The particular entitlements one espouses ob- 
viously depend upon one's definition of "normal" life. In practice, the emphasis has been on housing, schooling, work, friendship, and family life. Thus, the right to a normal life may imply policies which generate the respect of others, with no necessary tie to the choices made by the retarded themselves. The normalization principle may lead to policies that place the retarded in life situations that are close to those chosen by many normal people. Under this approach, individuals are not always given the right to live according to their own distinctive views of the good life. If some of the retarded feel oppressed when forced to normalize by settling down in a middle-class neighborhood and taking a regular job, then this kind of normalization is not consistent with autonomy. The possible conflict between this version of the normalization principle and a philosophy based on the development of autonomy depends upon the capacities of the particular mentally retarded person and on the way normalization is translated into specific policies.

Consider, first, the severely and profoundly retarded. For them, normalization has been taken to mean efforts to teach the rudiments of independent daily living (Yates 1970, pp. 332-34). This kind of training is difficult to interpret as the imposition of middle-class values. Even members of the radical fringe and the fascist party know how to dress themselves, speak and understand language, and drink from a cup. However, the principle has also been associated with the development of residential facilities with as few clients as possible (Ferleger and Boyd 1979). Here the conflict between the symbols of normal life and reality may be stark. Small residences with half a dozen clients may be unable to provide specialized care and could isolate the severely retarded person more fully than life in a larger institution (for evidence on the tenuous link between size and "quality," see Landesman-Dwyer and Sackett [1980]).

For the moderately and mildly retarded, the tension between normalization and autonomous choice is even more obvious. An advocate concerned with giving the retarded a normal life may find that this conflicts with policies that develop self-respect and autonomy. For example, if permitted to speak for themselves some retarded adults might well argue against deinstitutionalization and normalization and in favor of protective institutional care (Roos 1979, p. 617). Retarded children might find that mainstreaming in the educational system makes learning difficult. They might be better able to cope with the world as adults if they were initially segregated in special classes. ${ }^{12}$ If this were true, then advocates of normalization would find themselves with an awkward decision-making problem. Their interest in helping the adult retarded person cope with life is in conflict with their belief that the educational system should be organized to avoid stigmatizing children.

\section{ALLIANCES}

Although principle plays an especially critical role in shaping policy toward the retarded, private interests are also influential. Thus, it is important to see how different moral commitments support or oppose various private interests. This will help us to understand the present pattern of alliances.

12. There is no clear evidence on this point because students differ and because the quality of both special education and mainstream education can vary widely. Several of the writers in O'Donnell and Bradfield (1976) point out the need to reorganize the entire educational system, retrain teachers, and provide additional funds if mainstreaming is to succeed for both normal and handicapped children. See also Sarason and Doris (1979, pp. 393-412). Unfortunately, research on education in general is not much better than research on special education, so it is difficult to assess the impact of systematic changes (see Murnane 1980). 
First, consider the parents of retarded children and adults. Their political interests and activism depend in large part on their socioeconomic status. Wealthy parents do not need to ally with anyone. They can simply send their children to expensive private residential schools. ${ }^{13}$ Poor parents, especially those from minority ethnic and racial groups with a high incidence of mild retardation, ${ }^{14}$ face a special problem. Because of their poverty, they are likely to be less sympathetic to programs that favor the retarded over other poor people. Because of their minority group status, they will also wish to avoid programs that doubly label a person as both retarded and a member of a minority group. However, they would like to receive subsidies to supplement their meager incomes, and the general public may be more willing to aid the retarded than the poor.

In the postwar period, white middle-class parents whose children are severely or profoundly retarded have formed the core of political activists. Lacking both the resources of the rich and concern with stigma of minority groups, they have organized into Associations for Retarded Children (now Citizens)-ARCs - at the local, state, and federal level. ${ }^{15}$ In an alliance with legal activists, they have pushed for deinstitutionalization and normalization and for a developmental model of care. They have lobbied for high levels of public subsidy and for laws mandating equal or favored treatment for the retarded (PCMR 1977; Wiegerink and PosanteLobo 1977). Although both ARC parents and legal activists favor large public subsidies and a reorganized system of care irrespective of the costs imposed on others, conflicts have now arisen in several areas. First, most legal activists use respect-based arguments that are not tied to a person's capacity for autonomous choice and that leave out of account the interests of parents and siblings. The burden on a retarded person's family is not a primary concern of those committed to the right of the retarded to lead normal lives. Thus, legal activists may push for more home-based care than parents want to accept (Roos 1979; Wald 1976, p. 16). Second, the funding priorities of the groups are different. Middle-class parents are likely to be less egalitarian than principled advocates. Parents may be especially interested in supporting programs that provide funds to organizations that they

13. Conley (1973, p. 96) reports that in 1970 the direct annual accounting cost per patient of private residential facilities was $\$ 5,470$ for residential care and $\$ 22,265$ for private mental hospitals.

14. Mild retardation, as measured by tests and by the assessments of parents and teachers, is associated both with low income and with ethnic group status. In an SRI International Education Policy Research Center study (1979), teachers identified 1.33 percent of the youths as needing special resources for the retarded but labeled as retarded 3 percent of those from families earning less than $\$ 5,000$ per year and 0.15 percent from families earning more than $\$ 15,000$. Similarly, IQ tests identified as retarded (IQ less than 69) 7.7 percent of the youths whose family income was below $\$ 3,000,2.9$ percent with family income between $\$ 3,000$ and $\$ 5,000$, and 0.15 percent of those from families earning over $\$ 15,000$. The overall incidence using the IQ test was 2 percent (p. 35). Mercer (1973, pp. 78-79) shows that in one California city Mexican-Americans were much more likely to be judged as retarded than either blacks or Anglo-Americans. Correcting for socioeconomic conditions exacerbated the differences, suggesting that the difference was due to difficulties with the English language. Blacks also have a higher incidence of mental retardation on several measures (Mercer 1973, p. 78; SRI International Education Policy Research Center 1979, p. 35; Conley 1973, pp. $18-40,50-67)$. These differences may be mainly due to differences in socioeconomic conditions (Mercer 1973; Kamin 1974).

15. A recent study showed that minorities, the very wealthy, and the very poor are not significantly represented in the NARC (cited in PCMR 1977, p. 39). 
control, and they may resist pressures to admit more clients or to broaden the socioeconomic base of these organizations. ${ }^{16}$

A major source of disagreement over funding is the tension between those activists and parents who concentrate their efforts on the 5-6 percent of the retarded in the severe and profound category and activists and parents at all income levels whose main interest is the much larger number of mildly retarded or borderline people with one or another learning disability. Expensive training programs, humane living conditions, and prevention and early detection are the main concerns of the former group. Avoiding the stigma of labeling while still giving help is the concern of the latter. Those who want to concentrate on the severely and profoundly retarded are unlikely to make arguments that tie rights to the ability to make autonomous choices. In contrast, those whose chief concern is the mildly retarded are interested in programs that help them become integrated into the mainstream of society. Conflicts over principles can thus also become conflicts between the parents of children with different levels of retardation.

Second, voters, homeowners, and officials in public and private agencies whose primary purpose is not aid to the mentally retarded population are likely to support aid to the retarded on one or another philosophic ground. But they are acutely aware of at least some opportunity costs. They may thus support a utilitarian, happiness-based position on some issues. However, just as the groups with a personal interest in favoring the retarded give benefits a high weight and costs a low weight, other groups attach high weight to the costs imposed on them relative to the benefits gained by the retarded. Compared with disinterested utilitarian analysts, they are likely to support lower levels of subsidy and different kinds of aid. Taxpayers will be especially concerned with the question of coverage. They will be unimpressed with research which shows that community-based care is cheaper than institutional care on an individual-by-individual basis and may oppose a deinstitutionalization policy if more of the retarded will use the new community services, pushing tax bills up. Homeowners and public officials have particular concerns for the details of policy. Thus, homeowners frequently oppose group homes as neighbors (Kressel 1975; Chandler and Ross 1976 [with comments by Deutch 1976 and Simmons 1976]; Lippincott 1979, pp. 769-70; Mamula and Newman 1973, pp. 58-69), and officials who run other programs may fear a loss in resources, conflict with other goals, or an increase in a kind of client they cannot easily accommodate within their existing organizational framework. ${ }^{17}$

Finally, consider the heterogeneous group of people who provide services to the retarded. The relatively unskilled ward personnel in institutions for the retarded have overtly opposed deinstitutionalization because of the fear of losing their jobs (see Jones et al. [1975, chap. 4] and the discussion of Pennsylvania's deinstitutionalization efforts in Bradley [1978, pp. 94-98]). In contrast, professionals who work with the mentally retarded have in recent years generally embraced deinstitutionalization and normalization efforts. They have, however, spelled out

16. Both these propositions are illustrated by a case study of the Parents and Friends of Mentally Retarded Children of Bridgeport (reported in Aiken et al. 1975, p. 64).

17. Sarason and Doris (1979, pp. 359-66) discuss the opposition of "regular" teachers to mainstreaming. See Weatherley and Lipsky (1978) on the difficulty of implementing the Massachusetts law mandating education for the handicapped. Brewer and Kakalik (1979, chap. 13) discuss the federal Vocational Rehabilitation Act's emphasis on speedy placement. As a consequence, administrators of vocational rehabilitation programs have resisted accepting the severely and moderately retarded as clients. 
their support in a way that retains or enhances the position of their professional specialty. They can almost always be roughly classified as taking an equal respect position which holds that their own profession enhances the autonomy of the retarded. Thus, the Council for Exceptional Children, the professional organization of special education teachers, advocates mainstreaming so long as it involves a key role for specialized teachers for the retarded. Their policy statement (1971) argues for individualized instruction (p. 422), for beginning education early in life and ending it late (p. 421), for the use of specialized personnel (p. 432), and for increased professional training and supportive services (p. 423).

The National Association of Superintendents of Public Residential Facilities for the Mentally Retarded supports a move to smaller institutions but argues that total institutions will continue to be appropriate for some people and worries about the problem of quality control in a decentralized system (reported in Edelson [1979] and Gettings [1979]). While recognizing the current emphasis on deinstitutionalization, the group believes that publicly supported residential facilities "will always continue to be a necessary and important part of the continuum of services" (Edelson 1979, p. 1). Poor conditions in institutions are not seen to be the result of poor programs in the institutions but are, instead, believed to be caused by the lack of community alternatives.

The American Association on Mental Deficiency (AAMD), representing professionals who work with the mentally retarded, favors more community-based care so long as it is coupled with plenty of specialized professional services. Thus, the AAMD's statement on Rights of Mentally Retarded Persons (reprinted in Friedman 1976, pp. 179-86) includes: "A. The right to a publicly supported and administered comprehensive and integrated set of habilitative programs and services designed to minimize handicap or handicaps" (p. 183); "B. The right to a publicly supported and administered program of training and education including, but not restricted to, basic academic and interpersonal skills" (p. 184); "C. The right ... to a publicly administered and supported program of training toward a goal of maximum gainful employment . . " (p. 184). In discussing the right of the retarded to impartial guardians or advocates, they stress that, when courts appoint guardians, they should seek "competent professional advice" (p. 186).

State officials who control budgets for programs which aid the mentally retarded have supported some of the positions taken by the ARCs and the legal activists. Given the shift in professional opinion, they are not singlemindedly concerned with increasing their budgets. ${ }^{18}$ Instead, many administrators have become genuine converts to the normalization movement, making use of the issue to lobby for additional federal funds with little extra federal monitoring. ${ }^{19}$ They have, however, clashed with activists who hold respect-based positions over the importance of specialized professional care and the definition of community-

18. This is in contrast to the position of Niskanen (1971), who hypothesizes that bureau heads will seek to maximize the size of the bureau's budget.

19. In 1978, a task force at the U.S. Department of Health, Education, and Welfare (1978, annexes 2 and 3) presented a set of options to promote community-based care of the mentally disabled. They were advised by a working group of eight state mental health and mental retardation commissioners. The commissioners thought that increased Medicaid coverage for mental disease was a high priority and sought more social service (Title $\mathrm{XX}$ ) and HUD funds for the retarded. They supported deinstitutionalization efforts but opposed most additional federal regulatory oversight. 
based care. They may disagree, for example, about whether a state-run regional center for a hundred people counts as a community-based facility or whether it is necessary to establish group homes with only four or five people per house.

\section{MONEY, PRIVATE INTERESTS, AND IDEOLOGICAL PURITY}

The implementation of the normalization principle is complicated both by conflicts between principles and by tensions between private interests and moral positions. These conflicts are reflected in the political system's response. Politicians have reacted to the political activity of advocates for the retarded by giving them partial victories that do little damage to the politicians' reelection chances (for summaries of recent legislation see PCMR [1977, pp. 157-92] and Bradley [1978, pp. 38-47]). First, the U.S. Congress has passed laws with strong preambles and small appropriations. For example, the 1978 Amendments to the Developmental Disabilities Services and Facilities Construction Act (P.L. 95-602) contains sweeping statements in favor of deinstitutionalization and advocacy for the retarded and others who are "developmentally disabled." At the same time, federal appropriations are small compared with those for other federal social service programs and as a proportion of spending on the retarded. ${ }^{20}$ Second, Congress has ordered private organizations or lower-level governments to bear the costs. Although the burden on society may ultimately be quite large, members of Congress have tried to immunize themselves from responsibility for this result. Thus, the Education for All Handicapped Children Act of 1975 (P.L. 94-142) imposes most costs on state governments and local school districts. The law mandates that all handicapped children receive a free, appropriate public education by 1980 but provides limited funds and leaves the actual implementation to local school districts. $^{21}$ The Rehabilitation Act of 1973 requires employers and educational institutions which accept federal funds to accommodate the handicapped unless a person's problem interferes with learning or carrying out "essential" job tasks

20. The 1978 amendments contain the claim that the law's overall purpose is "to assist states to assure that persons with developmental disabilities receive the care, treatment, and other services necessary to enable them to achieve their maximum potential through a system which coordinates, monitors, plans and evaluates those services and which ensures the protection of the legal and human rights of persons with developmental disabilities" (92 Stat. 3004, P.L. 95-602, USC 6000, §502, amending 101). They also contain the statement that "it is in the national interest to strengthen programs, especially programs that reduce or eliminate the need for institutional care to meet the needs of persons with developmental disabilities." The definition of developmental disability has shifted over time as the law was amended. The original 1963 act referred only to mental retardation. By 1978, the term "mental retardation" had been eliminated. Appropriations under the basic support section of the Act are a tiny fraction of the money spent by the federal government on education, training, employment, and social services. In Connecticut, federal developmental disability funds cover less than 1 percent of the operating budget of the Department of Mental Retardation (Connecticut Department of Mental Retardation 1979a; Connecticut State Planning Council for Developmental Disabilities 1980).

21. The law authorizes federal grants based on the number of handicapped children, three to twenty-one years old, who received special education and related services multiplied by a growing fraction of average per-pupil expenditures for students in the United States. Because grants do not cover the costs of compliance, the costs to local school districts are likely to be substantial (Hartman 1979). Because of this, Roach (1978, p. 719) claims that some states have refused to accept the federal funds. 
(Rehabilitation Act of 1973 [29 USC $\S \S 701-794,1976$ ], as amended by P.L. 95-602, Titles I-IV, 92 Stat. 2955-3003) (see Olenick 1980; Bellamy et al. 1980). Once again, the government contractor or grantee, not the federal government, must bear the cost of this accommodation. ${ }^{22}$

Faced with limited federal funds specifically for the retarded, the advocates of normalization have countered by working through the bureaucracy to tap openended federal social programs. ${ }^{23}$ This has led to some awkward compromises between ideological purity and the desire for resources. The only federal sources of open-ended funds are the welfare system and Medicaid. For a few brief years, federal money for state social services was open ended. States, however, soon realized that they could use this program to obtain federal matching money for a large proportion of their budgets. Spending burgeoned, and, in response, Congress passed Title XX of the Social Security Act, which imposed a spending limit (see Derthick [1975] for an analysis of this case). In response, community-based programs for the mentally retarded that had expanded using social service funds (Hammer and Howse 1977) now received stricter scrutiny at the state level and had to compete with other claimants for funds. With social service funds limited, this left welfare and Medicaid. Both present ideological problems for a person committed to normalization. Any program which specifically lists the retarded as beneficiaries requires some kind of labeling process. Even if the program provides benefits in the form of medical care or extra income, these benefits are given in return for a label. Advocates for the retarded face a basic conflict between helping the retarded "pass" and helping them obtain special services. If you are not labeled, you cannot receive aid for your condition. If you are labeled that, in itself, may make further learning and adaptation difficult (Jones et al. 1975, p. 195; Potter 1977).

The problem of stigma is further exacerbated by the welfare system's definition of the eligible retarded as people unable to care for themselves ${ }^{24}$ and by Medicaid's understandable insistence on providing medical care. Since the welfare program for the retarded is designed for people so disabled that they cannot work, benefits are terminated if earnings are above a federally imposed ceiling (U.S. Department of Health, Education, and Welfare 1977, p. 48). "Normalization," however, has been taken to imply self-sufficiency through paid work (see Bellamy et al. 1980; Conley 1973). Administrators of sheltered workshops may thus wish to pay the retarded relatively high wages as a way of improving their self-respect and

22. When a person is retarded (or otherwise handicapped), it is not obvious what equal opportunity means. Since these people are frequently genuinely low-productivity workers, one must face the question of how much redesign of school programs and jobs or of capital is required to assure equal opportunity (Olenick 1980; Wikler 1979). Bellamy et al. (1980) and Conley (1973) argue strongly in favor of such redesign in the workplace.

23. They have also worked through the courts. See Kindred et al. (1976) and the Stanford Law Review Symposium (1979).

24. The federal Social Security Administration's definition of mental deficiency (recorded in Kakalik et al. 1976, pp. 425-26) is: "A. Severe mental and social incapacity as evidenced by marked dependence upon others for personal needs (e.g. bathing, washing, dressing, etc.) and inability to understand the spoken word and inability to avoid physical danger (fire, cars, etc.) and inability to follow simple directions and inability to read, write and perform simple calculations; or B. IQ of 49 or less (see $\$ 12.00 \mathrm{Cl}$ ); or C. IQ of 50 to 69 , inclusive (see $\$ 12.00 \mathrm{Cl}$ ) and: 1. Inability to perform routine, repetitive tasks; or 2. A physical or other mental impairment resulting in restriction of function." 
the attitudes of others toward them. Although the federal government does make some special allowance for employees of sheltered workshops, the ceiling implies that mentally retarded workers must earn very low wages in order to remain eligible for welfare.

Similarly, those pushing for normalization see all the retarded as capable of learning and want to describe retardation not as a medical problem but as a developmental problem that responds to "training." Thus, those seeking to provide services for the retarded have used Medicaid money to fund sheltered workshops and day programs. ${ }^{25}$ In an attempt to please Medicaid administrators, this can be called "vocational therapy" rather than "job training." The use of Medicaid money to provide such "therapy," however, is a currently controversial issue that has yet to be resolved by federal administrators. ${ }^{26}$

Some advocates, unhappy with the tension between their principles and the stated purposes of the laws that provide funding, have sought to change the laws and their accompanying regulations. For example, instead of seeking to pass new specialized acts for the retarded, they have tried to push Medicaid administrators toward the support of deinstitutionalization without moving them away from their basic commitment to providing medical care. Thus advocates have supported the imposition of stringent Medicaid regulations on public institutions. The federal government will not provide Medicaid funds to clients unless the institutions have complied with these regulations. ${ }^{27}$ One way to comply is to reduce institutional populations. This can be done both by moving old residents out and by refusing to admit new residents. Waiting lists have increased, ${ }^{28}$ and some of the mentally retarded are cared for in regular nursing homes with no special programs for the retarded. ${ }^{29}$ Thus, the drive for high-quality care in institutions and pressure from ARCs to get people out of institutions have combined to provide fewer people with public care, to push people into day programs that may not be suitable for them, and to keep many of the severely retarded in difficult family situations that are not obviously superior to institutional care. Partial "reform" may be worse than none at all (cf. Cameron 1978).

25. Bellamy et al. (1980) found that fourteen states used Medicaid funds for sheltered workshops or other adult day programs. A survey by the author indicated that this was done extensively in Connecticut.

26. Conversation with Ronald Conley, Office of Planning and Evaluation, U.S. Department of Health and Human Services, July 28, 1980.

27. Before July 15, 1980, federal Medicaid administrators would fund patients in institutions that met Medicaid staffing requirements but had not yet made capital improvements. The money for making these improvements had to be available, however. Since July 15 , 1980, no new institutions can be certified unless the improvements have actually been carried out (interview with Lynn Gravink, Deputy Commissioner, Connecticut Department of Mental Retardation, August 1, 1980).

28. In Connecticut, there was an "urgent" waiting list of 270 at the end of July 1980. This was an increase from 154 as of June 30, 1979, and fifty-eight as of October 1, 1978 (interview with Lynn Gravink; Connecticut Department of Mental Retardation 1979b, p. 28). See also Nebraska Regional Director's Council 1980, pp. 112-15.

29. The data on this practice are scanty, but it is a concern expressed by advocates for the retarded. Some of the people on urgent waiting lists live in nursing homes (Connecticut Department of Mental Retardation 1979b, p. 28; Nebraska Regional Director's Council 1980 , pp. 113-15), and in some states people have been moved from institutions for the mentally retarded to nursing homes. Scheerenberger $(1979$, p. 15) reports that, of the 8,723 people who left public facilities for the mentally retarded, 6.9 percent went to nursing homes. The data do not indicate, however, whether most of these people were sick or very old. 


\section{CONCLUSIONS}

The normalization movement faces the problem of all successful reforms-translating slogans into policy. Rallying cries are a useful way to get attention, but they are not very helpful when one must decide how to accommodate conflict (cf. Jones et al. 1975, p. 190; Zigler 1978). In this paper, I have isolated four kinds of conflict. The first is a conflict between principles: an individual may hold internally inconsistent or poorly articulated positions, or people may disagree with each other on which principles should guide policy. The second is a conflict between private interests and moral principles, and the third is the conflict between opposing private interests. The final conflict is an internal tension that activists face when their principles clash with the realities of political life. Should they hold out for their principles, or should they compromise in order to obtain money for services?

Since none of these conflicts can be resolved by a simple appeal to the normalization principle, this slogan appears to have outlived its usefulness. Reformers should not respond to this difficulty by inventing another slogan. Instead, people need to think through their positions, looking for inconsistencies and trying to sort out private interests from moral principles. Perhaps it is too optimistic to imagine that the current ad hoc, disjointed method of policymaking will be helped by an attempt to think through the practical implications of one's philosophical beliefs. Nevertheless, one can at least hope to discover which claims require a stronger empirical basis, which depend upon basic beliefs, and which further a private interest.

\section{REFERENCES}

The report of the U.S. President's Committee on Mental Retardation (1977) includes a history of care for the retarded in the United States and discusses current policy issues. Conley (1973) is the only systematic attempt to assess the benefits and costs of care for the retarded, although Brewer and Kakalik (1979) contains some more up-to-date information. Kindred et al. (1976) and Stanford Law Review Symposium (1979) are good introductions to the thinking of lawyers and other advocates for the retarded. Baker, Seltzer, and Seltzer (1974) describe the many different kinds of community residences, and Edgerton (1967) contains a series of case studies of retarded individuals who live independently in the community. Critical reviews of the literature on the costs and benefits of alternative types of care are found in Heal, Siegelman, and Switzky (1978) and Wieck (1980).

Ackerman, Bruce. 1980. Social Justice in the Liberal State. New Haven, Conn.: Yale University Press.

Aiken, Michael; Dewar, Robert; DiTomaso, Nancy; Hage, Jerald; and Zeitz, Gerald. 1975. Coordinating Human Services. San Francisco: Jossey-Bass Publishing Co.

Allen, David F., and Allen, Victoria S. 1979. Ethical Issues in Mental Retardation. Nashville, Tenn.: Abingdon Press.

Baker, Bruce L.; Seltzer, Gary B.; and Seltzer, Marsha Mailick. 1974. As Close as Possıble: Community Residences for Retarded Adults. Boston: Little, Brown \& Co.

Balla, David; Butterfield, Earl C.; and Zigler, Edward. 1974. Effects of Institutionalization on Retarded Children: A Longitudinal Cross-institutional Investigation. American Journal of Mental Deficiency 78:530-49.

Baumol, William. 1977. Economic Theory and Operatıons Analysıs. 4th ed. Englewood Cliffs, N.J.: Prentice-Hall, Inc.

Bellamy, G. Thomas; Sheehan, Martin R.; Horner, Robert; and Boles, Shawn. 1980. Community Programs for Severely Handicapped Adults: An Analysis of Vocational Opportunities. Journal of the Association for Severely Handicapped 5:307-24.

Bentham, Jeremy. 1976. A Utilitarian View. In Regan and Singer, eds. 
Biklen, Douglas. 1979. The Case for Deinstitutionalization. Social Policy 10:48-54.

Blatt, Burton, and Kaplan, Fred. 1966. Christmas in Purgatory. Boston: Allyn \& Bacon.

Bradley, Valerie. 1978. Deinstitutionalization of Developmentally Disabled Persons. Baltimore: University Park Press.

Brewer, Garry D., and Kakalik, James. 1979. Handicapped Children. New York: McGrawHill Publishing Co.

Bronston, William G. 1976. Concepts and Theory of Normalization. In The Mentally Retarded Child and His Family, ed. Richard Koch and James Dobson, pp. 490-516. Rev. ed. New York: Brunner/Mazel.

Broome, John. 1978. Trying to Value a Life. Journal of Public Economics 9:91-100.

Broome, John. 1979. Trying to Value a Life: A Reply. Journal of Public Economics 12:259-62.

Buchanan, James, and Faith, Roger. 1979. Trying Again to Value a Life. Journal of Public Economics 12:245-48.

Budoff, Milton, and Gottlieb, Jay. 1976. Special Class EMR Children Mainstreamed: A Study of an Aptitude (Learning Potential) $\times$ Treatment Interaction. American Journal on Mental Deficiency 81:1-11.

Cameron, James M. 1978. Ideology and Policy Termination: Restructuring California's Mental Health System. Public Policy 26:533-70.

Center on Human Policy. 1979. The Community Imperative: A Refutation of All Arguments in Support of Institutionalizing Anybody because of Mental Retardation. Mimeographed. Syracuse, N.Y.: Center on Human Policy, Syracuse University.

Chandler, JoAnn, and Roos, Sterling, Jr. 1976. Zoning Restrictions and the Right to Live in the Community. In Kindred et al., eds., pp. 305-43.

Conley, Ronald. 1973. The Economics of Mental Retardation. Baltimore: Johns Hopkins University Press.

Connecticut Department of Mental Retardation. 1979a. Annual Report, 1978-1979. Mimeographed. Hartford.

Connecticut Department of Mental Retardation. 1979b. Project Challenge: Residential Services Plan: Update of Resources and Needs. Mimeographed. Hartford.

Connecticut State Planning Council for Developmental Disabilities. 1980. Development Disabilities, Three Year State Plan. Mimeographed. Hartford.

Council for Exceptional Children. 1971. Policy Statement: Call for Response. Exceptional Children 37:421-33.

Derthick, Martha. 1975. Uncontrollable Spending for Social Services Grants. Washington, D.C.: Brookings Institution.

Deutch, John. 1976. Reaction Comment. In Kindred et al., eds., pp. 343-49.

Edelson, David. 1979. Deinstitutionalization: Avoiding Disaster. Mimeographed. National Association of Superintendents of Public Residential Facilities.

Edgerton, Robert B. 1967. The Cloak of Competence. Berkeley: University of California Press.

Feldman, Boris. 1979. Mental Disability and the Right to Vote. Yale Law Journal 88:1644-64.

Ferleger, David, and Boyd, Penelope A. 1979. Anti-Institutionalization: The Promise of the Pennhurst Case. Stanford Law Review 31:717-52.

Fine, M. J., and Caldwell, T. E. 1967. Self-Evaluation of School-related Behavior of Educable Mentally Retarded Children: A Preliminary Report. Exceptional Children 33:324.

Fredericks, H. D. Bud; Baldwin, Victor; Grove, David; Moore, William; Riggs, Cheryl; and Lyons, Barbara. 1978. Integrating the Moderately and Severely Handicapped Preschool Child into a Normal Day Care Setting. In Early Intervention and the Integration of Handicapped and Nonhandicapped Children, ed. Michael J. Guralnick, pp. 191-206. Baltimore: University Park Press.

Friedman, Paul R. 1976. The Rights of Mentally Retarded Persons. New York: Avon Books. Gettings, Robert. 1979. Outline of Discussion Topics: NASMRPD White Paper on the Future of Residential Services for Mentally Retarded Persons. Mimeographed. National Association of Superintendents of Public Residential Facilities. 
Gibbons, Frederick, and Gibbons, Barbara Noone. 1980. Effects of the Institutional Label on Peer Assessments of Institutionalized EMR Persons. American Journal of Mental Deficiency 84:602-9.

Gilhool, Thomas. The Right to Community Services. 1976. In Kindred et al., eds., pp. 173-217.

Hammer, Paula, and Howse, Jennifer. 1977. Legislation. In Paul, Stedman, and Neufeld, eds., pp. 140-65.

Hartman, William. 1979. Estimating the Costs of Educating Handicapped Children: A Resource-Cost Model Approach-Summary Report. Program Report no. 79-B15. Palo Alto, Calif.: Institute for Research on Educational Finance and Governance, School of Education, Stanford University.

Heal, Laird; Siegelman, Carol; and Switzky, Harvey. 1978. Research on Community Residential Alternatives for the Mentally Retarded. In International Review of Research in Mental Retardation, ed. N. R. Ellis, vol. 9, pp. 209-49. New York: Academic Press.

Hochman, Harold, and Rodgers, James. 1969. Pareto Optimal Redistribution. American Economic Review 59:543-57.

Jones, Kathleen. With John Brown, W. J. Cunningham, Julian Roberts, and Peter Williams, 1975. Opening the Door: A Study of New Policies for the Mentally Handicapped. London: Routledge \& Kegan Paul.

Jones-Lee, M. W. 1979. Trying to Value a Life: Why Broome Does Not Sweep Clean. Journal of Public Economics 12:249-56.

Kakalik, J. S.; Brewer, Garry D.; Prusoff, L. L.; Armor, D. C.; and Morrison, P. A. 1976. Mental Health and Mental Retardation Services in Nevada. R-1800-FLF. Santa Monica, Calif.: Rand Corp.

Kamin, Leon. 1974. The Science and Politics of IQ. Potomac, Md.: Lawrence Erlbaum Associates.

Kant, Immanuel. 1976. Duties to Animals. In Regan and Singer, eds., pp. 122-23.

Kennedy, R. A. 1966. A Connecticut Community Revisited: A Study of Social Adjustment of a Group of Mentally Deficient Adults in 1948 and 1960. Hartford: Connecticut State Department of Health, Office of Mental Retardation.

Kindred, Michael; Cohen, Julius; Penrod, David; and Shaffer, Thomas, eds. 1976. The Mentally Retarded Catizen and the Law. New York: Free Press.

Kressel, Laurence. 1975. The Community Resident Movement: Land Use Conflicts and Planning Imperatives. New York University Review of Law and Social Change 5:137-62.

Lakoff, Sanford. 1964. Equality in Political Philosophy. Cambridge, Mass.: Harvard University Press.

Landesman-Dwyer, Sharon, and Sackett, Gene P. 1980. Relationship of Size to Resident and Staff Behavior in Small Community Residences. American Journal of Mental Deficiency 85:6-17.

Lerner, A. P. 1944. The Economics of Control. New York: Macmillan Publishing Co.

Lippincott, Marcia K. 1979. A Sanctuary for People: Strategies for Overcoming Zoning Restrictions on Community Homes for Retarded Persons. Stanford Law Review 31:767-83.

Mamula, Richard A., and Newman, Nate. 1973. Community Placement of the Mentally Retarded. Springfield, Ill.: Charles C. Thomas Publishers.

Matson, John; Marchetti, Allen; and Adkins, Joyce. 1980. Comparison of Procedures for Mentally Retarded Adults. American Journal of Mental Deficiency 84:487-94.

Mercer, Jane. 1973. Labeling the Retarded. Berkeley: University of California Press.

Mill, John Stuart. 1976. A Defense of Bentham. In Regan and Singer, eds., pp. 131-32.

Montague, Phillip. 1980. Two Concepts of Rights. Philosophy and Public Affairs 9:372-84.

Murnane, Richard. 1981. Interpreting the Evidence on School Effectiveness. Teachers College Record 83:19-35.

Nebraska Regional Director's Council. 1980. Three Year Plan, 1979-1982: Nebraska Community-based Mental Retardation Program. Mimeographed. Omaha. 
Nirje, Bengt. 1976. The Normalization Principle. In Changing Patterns in Residentzal Services for the Mentally Retarded, ed. R. Kugel and Ann Shearer, pp. 231-40. Rev. ed. Washington, D.C.: President's Committee on Mental Retardation.

Niskanen, William. 1971. Bureaucracy and Representative Government. Chicago: AldineAtherton.

Nozick, Robert. 1974. Anarchy, State and Utopia. New York: Basic Books.

O'Donnell, Patrick, and Bradfield, Robert, eds. 1976. Mainstreaming: Controversy and Consensus. San Rafael, Calif.: Academic Therapy Publications.

Olenick, Donald Jay. 1980. Accommodating the Handicapped: Rehabilitating Section 504 after Southeastern. Columbia Law Review 80:171-91.

Paul, James L.; Stedman, Donald J.; and Neufeld, G. Ronald, eds. 1977. Deinstitutionalization: Program and Policy Development. Syracuse, N.Y.: Syracuse University Press.

Potter, Ralph. 1977. Labeling the Mentally Retarded: The Just Allocation of Therapy. In Ethics in Medicine: Historical Perspective and Contemporary Concerns, ed. Stanley J. Reiser, Arthur J. Dyck, and William J. Curran, pp. 626-31. Cambridge, Mass.: MIT Press.

Rae, Douglas. 1979. The Egalitarian State: Notes on a System of Gontradictory Ideals. Daedalus 108:27-54.

Rawls, John. 1971. A Theory of Justıce. Cambridge, Mass.: Harvard University Press.

Rawls, John. 1979. A Well-ordered Society. In Philosophy, Politics and Society, ed. Peter Laslett and James Fishkin, pp. 6-20. 5th ser. New Haven, Conn.: Yale University Press.

Regan, Tom. 1980. Utilitarianism, Vegetaiianism, and Animal Rights. Phılosophy and Public Affairs 9:305-24.

Regan, Tom, and Singer, Peter, eds. 1976. Animal Rights and Human Obligations. Englewood Cliffs, N.J.: Prentice-Hall, Inc.

Rivera, Geraldo. 1972. Willowbrook: A Report on How It Is and Why It Doesn't Have to Be That Way. New York: Random House.

Roach, Randy. 1978. The Least Restrictive Environment Section of the Education for All Handicapped Children Act of 1975: A Legislative History and an Analysis. Gonzaga Law Review 13:717-19.

Robinson, Joan. 1966. An Essay on Marxian Economics. 2d ed. London: Macmillan Publishing Co.

Roos, Philip. 1979. The Law and Mentally Retarded People: An Uncertain Future. Stanford Law Review 31:613-24.

Rosenberg, Norman S., and Friedman, Paul R. 1979. Developmental Disability Law: A Look into the Future. Stanford Law Review 31:817-29.

Rowan, Beverly. 1976. Corrections. In Kindred et al. eds., pp. 650-75.

Sanders, Richard M. 1975. Behavior Modification in a Rehabilitatıon Facility. Carbondale: Southern Illinois University Press.

Sarason, Seymour, and Doris, John. 1979. Educational Handicap: Public Policy and Social History. New York: Free Press.

Schalock, Robert L., and Harper, Robert S. 1978. Placement from Community-based MR Programs: How Well Do Clients Do? Amercan Journal on Mental Deficiency 83:240-47.

Scheerenberger, R. C. 1977. Deinstitutionalization in Perspective. In Paul, Stedman, and Neufeld, eds., pp. 3-14.

Scheerenberger, R. C. 1979. Public Residential Services for the Mentally Retarded. Madison, Wis.: National Association of Superintendents of Public Residential Facilities for the Mentally Retarded, Central Wisconsin Center for the Developmentally Disabled.

Schoenfeld, Benjamin. 1974. Human Rights for the Mentally Retarded: Their Recognition by the Providers of Service. Human Rights 4:31-65.

Schwartz, Herman. 1976. Comment. In Kindred et al. eds., pp. 675-77.

Sen, A. K. 1970. Collective Choice and Social Welfare. San Francisco: Holden-Day.

Sen, A. K. 1973. On Economic Inequality. New York: W. W. Norton \& Co.

Simmons, Peter. 1976. Reaction Comment. In Kindred et al., eds., pp. 349-55. 
Singer, Peter. 1976. All Animals Are Equal. In Regan and Singer, eds., pp. 148-62.

SRI International Education Policy Research Center. 1979. Identification of Handicapped Students (Ages 12-17) Using Data from Teachers, Parents and Tests. Research Note EPRC 24. Menlo Park, Calif.: SRT.

Suppes, P. 1966. Some Formal Models of Grading Principles. Synthese 16:284-306.

Symposium: Mentally Retarded People and the Law. 1979. Stanford Law Review 31:541-829.

U.S. Department of Health, Education, and Welfare. 1977. Key Federal Regulations Affecting the Handicapped, 1975-1976. Washington, D.C.: Government Printing Office.

U.S. Department of Health, Education, and Welfare, Deputy Assistant Secretary for Planning and Evaluation. 1978. Interim Report of the Task Force on Deinstitutionalization of the Mentally Disabled. Mimeographed. Washington, D.C.: not published.

U.S. Department of Labor, Employment Standards Administration, Employment and Training Administration. 1979. Sheltered Workshop Study. Vol. II: Study of Handicapped Clients in Sheltered Workshops and Recommendations of the Secretary. Washington, D.C.: Government Printing Office.

U.S. President's Committee on Mental Retardation (PCMR). 1977. Mental Retardatıon Past and Present. Washington, D.C.: Government Printing Office.

Wald, Patricia. 1976. Basic Personal and Civil Rights. In Kindred et al. eds., pp. 3-26.

Weatherley, Richard, and Lipsky, Michael. 1978. Street-level Bureaucrats and Institutional Innovation: Implementing Special Education Reform. In Making Change Happen? ed. Dale Mann, pp. 49-77. New York: Teachers College Press, Columbia University.

Wieck, Coleen. 1980. The Cost of Community and Public Residential Facility Care for Mentally Retarded People in the United States. Mimeographed. Minneapolis: Department of Psychoeducational Studies, University of Minnesota.

Wiegerink, Ronald, and Posante-Lobo, Rebecca. 1977. Consumerism. In Paul, Stedman, and Neufeld, eds., pp. 63-79.

Wikler, Daniel. 1979. Paternalism and the Mildly Retarded. Philosophy and Public Affarrs 8:377-92.

Williams, Alan. 1979. A Note on "Trying to Value a Life." Journal of Publıc Economıcs 12:257-58.

Wolfensberger, Wolf. 1976. The Origin and Nature of Our Institutional Models. In Changing Patterns in Residentzal Services for the Mentally Retarded, ed. R. Kugel and Ann Shearer, pp. 35-82. Rev. ed. Washington, D.C.: President's Committee on Mental Retardation.

Yates, Aubrey J. 1970. Behavior Therapy. New York: John Wiley \& Sons.

Zigler, Edward. 1978. National Crisis in Mental Retardation Research. American Journal of Mental Deficiency 83:1-8. 